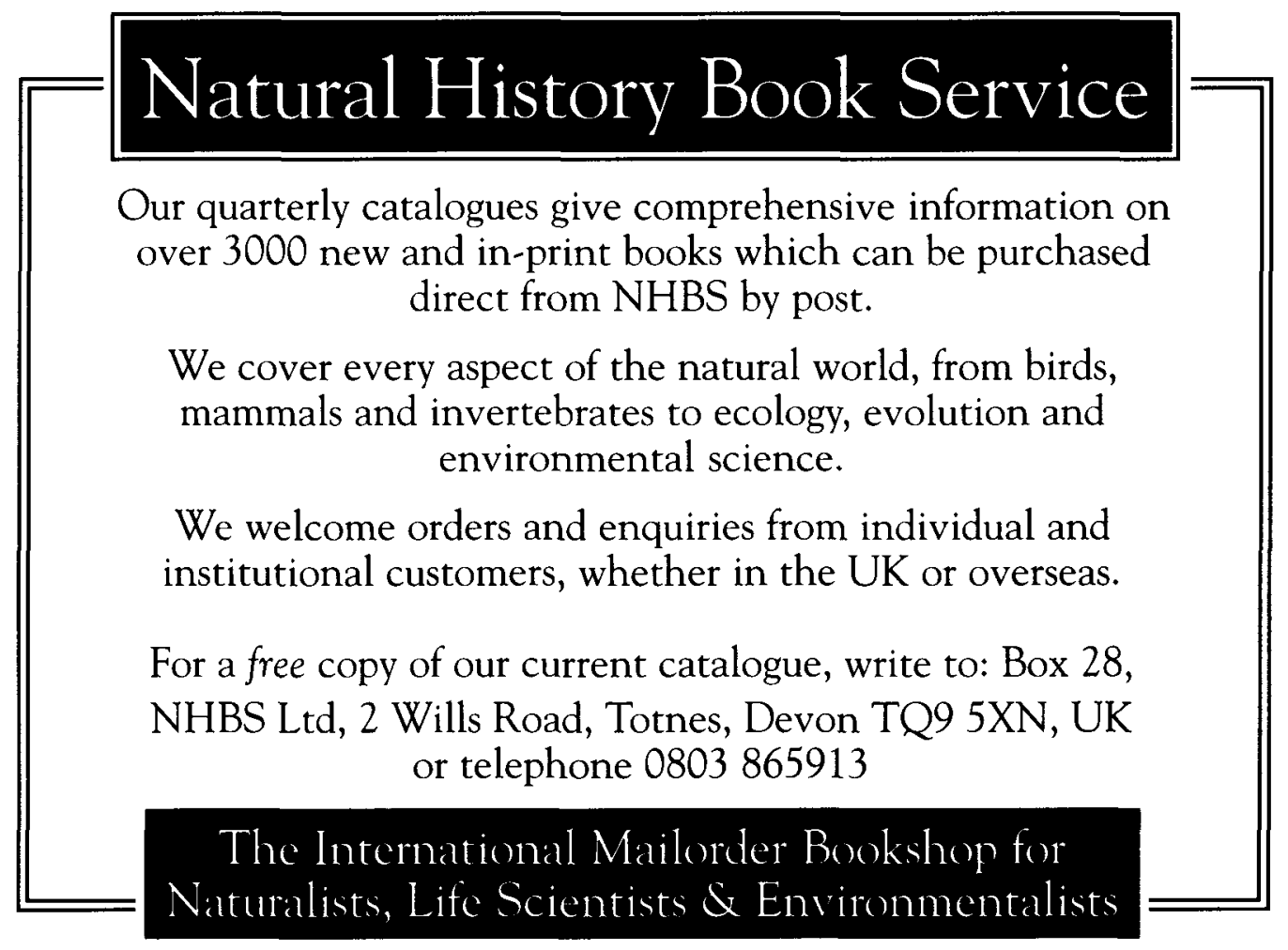




\title{
The journals of the British Ecological Society
}

\section{Journal of Ecology}

\author{
Edited by J.A. Lee, J. White and J. Etherington
}

The Journal of Ecology is one of the world's oldest and most respected publications in the science. The objects of the journal are: (1) to foster and promote the study of vegetation and ecology, especially in the British Isles; (2) to afford an outlet for original work on these subjects; (3) as far as possible to present a record of the commentary on the progress of these studies throughout the world. The journal includes the series Biological Flora of the British Isles, which appear in most issues of the journal but are also available as separate offprints on standing order.

\section{Journal of Animal Ecology}

\section{Edited by L.R. Taylor and J.M. Elliott}

This leading international journal publishes papers on original research in all branches of animal ecology. A balance is sought between aquatic and terrestrial environments, between invertebrates and vertebrates, and between theoretical, experimental and analytical approaches to soundlybased field data. Occasional purely descriptive, theoretical or review papers may be published at the discretion of the editors on animals or concepts of special interest or as part of an extensive development of a subject or as an adjunct to a long-term project.

\section{Journal of Applied Ecology}

\section{Edited by W.C. Block, J. Miles and N.R. Webb}

The journal publishes the results of original research in which ecological ideas and methods are applied to the study, conservation, management, control, development and use of natural resources in the widest sense. The editors select for publication only material of the highest scientific standards and this policy has attracted contributions by the world's leading authorities.

\section{Functional Ecology}

\section{Edited by P. Calow and J. Grace}

Functional Ecology publishes short, original papers in a wide range of ecological topics, but particularly emphasizing the fields of physiological, biophysical and evolutionary ecology. Papers may describe experimental, observational or theoretical studies on terrestrial, freshwater or marine systems. The Editors are especially keen to publish papers that blend between these subject areas. Work that is purely descriptive and/or concerned exclusively and specifically with the population dynamics of organisms will not be accepted unless it sheds light on those specific areas mentioned above.

\section{Subscription Information}

The Journal of Ecology is published quarterly, the Journal of Animal Ecology and Journal of Applied Ecology are published three times a year and Functional Ecology is published bimonthly. The subscription rates for 1989 are, for each one: $£ 92.00$ (UK), $£ 110.00$ (overseas), US $\$ 189.00$ (USA \& Canada) post free. Subscriptions and free specimen copies are available from:

Blackwell Scientific Publications Ltd, P.O. Box 88, Oxford, England.

\section{Blackwell Scientific Publications P.O. Box 88, Oxford, England}




\section{Handbook of}

\section{Marine Mammals Volume 4} River Dolphins and the

\section{Larger Toothed Whales}

edited by

Sam H. Ridgway, Naval Ocean Systems Center, San Diego, Califomia

Richard Harrison, University of Cambridge, England f49.50, ISBN: 0-12-588504-0, 464pp, April 1989

This series is an authoritative guide to the biology of marine mammals in their natural environment. Perfect for use in the field as a practical guide to identification, these books provide an abundance of factual information and reference photographs.

\section{Fish Vaccination}

edited by

A.E. Ellis, Marine Laboratory, DAFS, Aberdeen, England f19.95, ISBN: 0-12-237485-1, 272pp, 1988

Fish disease is a major economic threat to the aquaculture industry. One key to combating this problem is the successful development and utilization of vaccines. This book provides clear and concise essential information on:

the theory of vaccination

the commercial production, legal restrictions and marketing of vaccines

- the practical use of vaccines on fish farmslimitations and attendant problems

- Vaccination strategies for the most common and commercially important bacterial, viral, and parasitic diseases of fish.

A glossary of terms is included as an appendix to the book.

Fish immunologists and pathologists, fish farmers, students and teachers of aquaculture, and veterinarians will find this text an indispensable guide.

\section{Advances in Marine Biology Volume 25}

edited by

J.H.S. Blaxter, Dunstaffrage Marine Reseanch Laboratory, Scotland

A.J. Southward, The Labonatory, Plymouth, England E35.00, ISBN: 0-12-026125-1, 288pp, June 1989
Volume 25 of this authoritative review series continues the high standard set by the editors in the past. Marine biologists everywhere have come to value and enjoy the wide variety of thought-provoking papers written by invited experts.

CONTENTS: K.M. Bailey and E.D. Houde, Predation on Eggs and Larvae of Fish. S.V. Boletsky, Early Life History of Cephalopods. I. Theodorides, Parasites of Zooplankton. A.C. Brown, J.M.E. Stenton-Dozey, and E.R. Truman, Sandy Beach Bivalves and Gastropods.

\section{Fish Nutrition (2/E)}

John E. Halver, University of Washington, Seattle Ł91.00, ISBN: 0-12-319651-5, 798pp, March 1989 The second edition of this comprehensive treatise gives a 15-year update on the nutrients required by fish and describes the roles and functions of these nutrients in fish physiology and metabolism. This volume is a fundamental source book and reference work and features:

- all elements of fish nutrition

- nutrient requirements of various fish species

- nutrient roles in metabolism

- digestive physiology of fish

- intermediary metabolism in fish

- diet formulations and preparations.

The contributors review knowledge as developed within the last 15 years; extend the principles of fish nutrition to more species, and particularly to ones that are the targets for aquaculture or preservation because they are endangered or threatened; and discuss theories about the role of vitamins and other nutrients, including nutrient balance in fish physiology, development, and reproduction.

This volume will be an indispensable souncebook to anyone interested in the topic of fish nutrition.

\section{Fish Pathology (2/E)}

R.J. Roberts, Institute of Aquaculture, University of Stirling, Scotland

E75.00, ISBN: 0-7020-1314-5, 448pp, April 1989

The only major constraint in the successful economic development of intensive fish farming is disease. This book addresses the problem in detail-covering a wide range of species from around the world, with over $\mathbf{4 0 0}$ illustrations. The second edition contains more information on the virology, histopathology and immunology of fish as well as new, definitive descriptions of previously unknown diseases. It has been written by one of the leading authorities in the field.

\section{A Baillière Tindall publication}

All prices subject to change without notice 


\section{CENTENNIAL MEETING OF THE AMERICAN SOCIETY OF ZOOLOGISTS AND \\ AMERICAN MICROSCOPICAL SOCIETY, ANIMAL BEHAVIOR SOCIETY, THE CRUSTACEAN SOCIETY, INTERNATIONAL ASSOCIATION OF ASTACOLOGY, AND SOCIETY OF SYSTEMATIC ZOOLOGY}

Marriott Copley Place - Westin Copley Place - Copley Plaza Hotel Boston, Massachusetts - December 27.30

Abstract Deadline: August 4,1989 Call for Papers: April, 1989 for Oral and Poster Presentations. Note that posters are particularly encouraged, and the ASZ Division of History and Philosophy of Biology welcomes posters as a second paper.

Schedule for December 27, 28 and 29: Plenary Lectures • Oral Papers • Poster Presentations

Schedule for December 30: Society/Divisional Symposia and Workshops plus Elephant and the Blind Zoologists Program

PLENARY LECTURES DECEMBER 27, 28 AND 29:

Wednesday, December 27

EMERGING SYSTEMS: COMPONENTS OF ORGANISMS INCLUDING IONS, MOLECULES, GENES AND CELLS (Keith Porter, Joseph Bonaventura, Gary W. Litman, and Lynn Margulis)

Thursday, December 28

ORGANISMS AS INTEGRATED SYSTEMS: CELLS, ORGANS, TISSUES

(Hugh Huxley, Howard A. Bern, Berta Scharrer and Marvalee H. Wake)

Friday, December 29

ORGANISMAL SYSTEMS: ANIMALS AND BEHAVIOR

(George O. Mackie, Masakazu Konishi, Stephen J. Gould and E.O. Wilson)

Art, Book and instrument Exhibits at the

Westin Hotel and Harvard University.

Programs on Public Affairs, Ethics, and Tools and Technologies

ASZ Symphony Orchestra

Impersonation of Charles Darwin by Richard Eakin

Socials include a party at the New England Aquarium, closing banquet honoring international guests, and the Third Annual Endowment Auction

Meeting Hosted by Harvard University and Northeastern University

Karel F. Liem and Kenneth P. Sebens

Co-Chairpersons of the Local A.rangements Committee

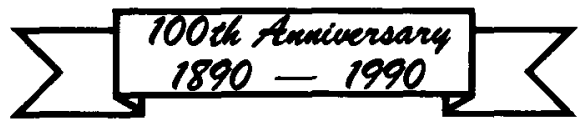

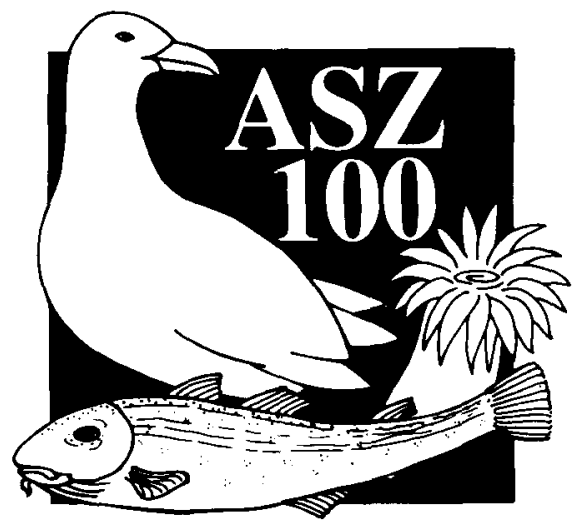

For more information, contact: Mary Adams-Wiley, Executive Officer American Society of Zoologists 104 Sirius Circle, Thousand Oaks, CA 91360 Phone: (805) 492-3585 FAX: (805) 492-0370 
Cover: The photograph on the outside of the cover was taken by David Nicholson at Pedney Beach, Cornwall.

Inside front cover: Scanning electron micrographs of coccolithophorids (photographs by Derek Harbour).

Upper: Rhabdosphaera claviger Murray and Blackman ( $9 \mu \mathrm{m}$ diameter).

Lower: Discosphaera tubifera (Murray and Blackman) Ostenfeld (8 $\mu \mathrm{m})$.

Inside back cover: Scanning electron micrographs of coccolithophorids (photographs by Derek Harbour).

Upper: Helicosphaera carteri (Wallich) Kamptner $(15 \mu \mathrm{m})$.

Lower: Umbilicosphaera hulburtiana Gaarder $(9 \mu \mathrm{m})$.

(C) The Marine Biological Association of the United Kingdom 1989

CAMBRIDGE UNIVERSITY PRESS

THE PITT BUILDING, TRUMPINGTON STREET, CAMBRIDGE CB2 1RP

32 EAST 57TH STREET, NEW YORK, NY 10022, USA

10 STAMFORD ROAD, OAKLEIGH, MELBOURNE 3166, AUSTRALIA

Printed in Great Britain by the University Press, Cambridge 

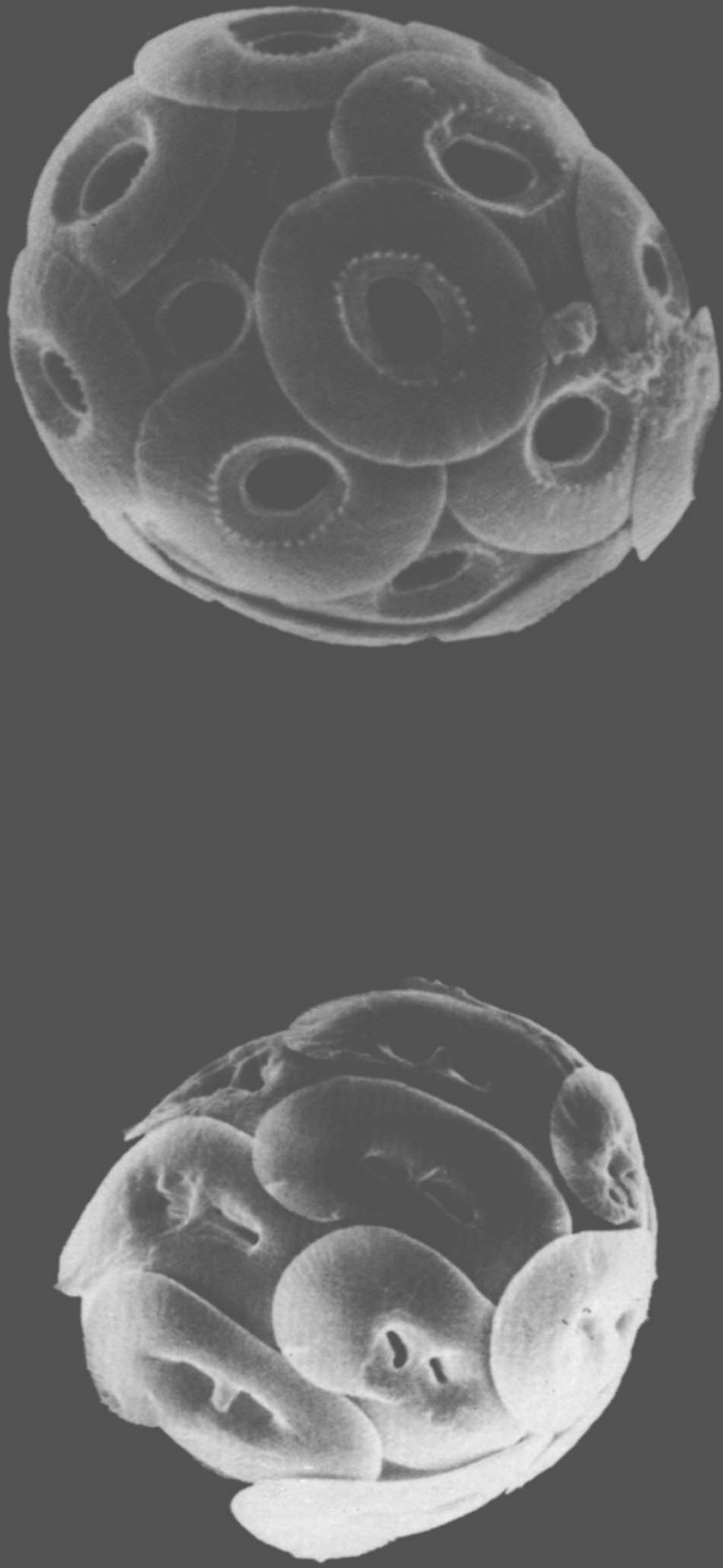


\section{JMBA}

JOURNAL OF THE MARINE BIOLOGICAL ASSOCIATION OF THE UNITED KINGDOM

VOLUME 69:3 AUGUST 1989

\section{CONTENTS}

Partensky. F., Le Boterff, J. and Verbist, J.-F. Does the fish-killing dinoflagellate Gymnodinium cf. nagasakiense produce cytotoxins?

Furman, E. R. and Crisp, D. J. Biometrical changes during growth of isolated individuals of Balanus improvisus

Bannister, N. J. and Herring. P. J. Distribution and structure of luminous cells in four marine copepods

Rogers, S. I. Seasonal variations in fecundity and egg size of the common goby, Pomatoschistus microps

Castro, B. G. and Guerra, A. Feeding pattern of Sepia officinalis (Cephalopoda: Sepiodidea) in the Ria de Vigo (NW Spain)

Kuhlenkamp. R. Photomorphogenesis in early development of Tilopteris mertensii (Tilopteridales: Phaeophyceae)

Goulletquer, P. and Wolowicz, M. The shell of Cardium edule, Cardium glaucum and Ruditapes philippinarum: organic contents, proximate composition and energy value, as determined by different methods

Bodin, P. and Jackson, D. F. A comparison of the intertidal harpacticoid copepod assemblages of sandy beaches in Galway Bay (Ireland) and Northern Brittany (France)

Dauvin, J.-C. and Joncourt, M. Energy values of marine benthic invertebrates from the western English Channel

Bone, Q. On the muscle fibres and locomotor activity of doliolids (Tunicata : Thaliacea)

Whittington, I. D. and Kearn, G. C. Rapid hatching induced by light intensity reduction in the polyopisthocotylean monogenean Plectanocotyle gurnardi from the gills of gurnards (Triglidae), with observations on the anatomy and behaviour of the oncomiracidium

Andersen, V. and Nival, P. Modelling of phytoplankton population dynamics in an enclosed water column

Batty, R. S. Escape responses of herring larvae to visual stimuli

Gordon, J. D. M. and Duncan, J.A. R. A note on the distribution and diet of deep-water rays (Rajidae) in an area of the Rockall Trough

Kempf, S. C. and Todd, C. D. Feeding potential in the lecithotrophic larvae of Adalaria proxima and Tritonia hombergi: an evolutionary perspective

Greenwood, J. G., Jones, M. B. and Greenwood, J. Salinity effects on brood maturation of the mysid crustacean Mesopodopsis slabberi

Young. C. M., Cameron, J. L. and Eckelbarger, K. J. Extended prefeeding period in planktotrophic larvae of the bathyal echinoid Aspidodiadema jacobyi

White, M. E., Powell, E. N., Wilson, E. A. and Ray, S. M. The spatial distribution of Perkinsus marinus, a protozoan parasite, in relation to its oyster host (Crassostrea virginica) and an ectoparasitic gastropod (Boonea impressa)

Abstracts: Light and Life in the Sea

PAGE

\section{1}

